IZA DP No. 7075

Heterogeneity in Union Status and Employee Well-Being

Getinet Haile

Alex Bryson

Michael White

December 2012 


\title{
Heterogeneity in Union Status and Employee Well-Being
}

\author{
Getinet Haile \\ University of Nottingham and IZA
}

Alex Bryson

NIESR and CEP

Michael White

PSI

\section{Discussion Paper No. 7075 \\ December 2012}

\author{
IZA \\ P.O. Box 7240 \\ 53072 Bonn \\ Germany \\ Phone: +49-228-3894-0 \\ Fax: +49-228-3894-180 \\ E-mail: iza@iza.org
}

Any opinions expressed here are those of the author(s) and not those of IZA. Research published in this series may include views on policy, but the institute itself takes no institutional policy positions. The IZA research network is committed to the IZA Guiding Principles of Research Integrity.

The Institute for the Study of Labor (IZA) in Bonn is a local and virtual international research center and a place of communication between science, politics and business. IZA is an independent nonprofit organization supported by Deutsche Post Foundation. The center is associated with the University of Bonn and offers a stimulating research environment through its international network, workshops and conferences, data service, project support, research visits and doctoral program. IZA engages in (i) original and internationally competitive research in all fields of labor economics, (ii) development of policy concepts, and (iii) dissemination of research results and concepts to the interested public.

IZA Discussion Papers often represent preliminary work and are circulated to encourage discussion. Citation of such a paper should account for its provisional character. A revised version may be available directly from the author. 


\section{ABSTRACT}

\section{Heterogeneity in Union Status and Employee Well-Being*}

This paper examines if workplace and co-worker union status affect employee wellbeing. In contrast to the literature focusing on links between one's own membership status and wellbeing, we focus principally on non-union employees. We find that being in a union workplace and having union co-workers affect the job satisfaction of non-union employees negatively. No such a link is found with respect to job-related anxiety.

JEL Classification: J5, J51, J28, J82

Keywords: trade union, job-related anxiety, job satisfaction, linked employer-employee data

Corresponding author:

Getinet Haile

Division of Industrial Economics

Nottingham University Business School

North Building, Jubilee Campus

Wollaton Road

Nottingham, NG8 1BB

United Kingdom

E-mail: getinet.haile@nottingham.ac.uk

\footnotetext{
* The authors acknowledge the Department of Trade and Industry, the Economic and Social Research Council, the Advisory, Conciliation and Arbitration Service and the Policy Studies Institute as the originators of the 2004 Workplace Employment Relations Survey data, and the Data Archive at the University of Essex as the distributor of the data. The National Centre for Social Research was commissioned to conduct the survey fieldwork on behalf of the sponsors. None of these organisations bears any responsibility for the authors' analysis and interpretations of the data. The usual disclaimer applies.
} 


\section{Introduction}

A large empirical literature indicates that reported job satisfaction is lower among trade union members than it is among their non-member counterparts, ceteris paribus. This is a puzzle, given that unions are meant to improve the pay and working conditions of their members, which should in turn enhance the satisfaction and wellbeing of members. Considerable effort has been made to explain this puzzling empirical regularity (see Bryson et al. 2010 and Green and Heywood 2010 for recent reviews).

The literature typically compares average differences in satisfaction between members and non-members. However, there may well be a link between satisfaction (and other aspects of wellbeing) and membership that goes beyond individual membership status. Recent evidence (Bryson et al. 2010), for example, indicates the crucial importance of bargaining coverage at the workplace in explaining the link between membership and satisfaction. This suggests the 'union environment' at the workplace and membership status of co-workers may be linked to the wellbeing of non-members.

We depart from the literature in this paper by comparing the wellbeing of non-union workers working with and without union workers. The paper is the first to focus on non-union workers to further understanding of union effects on worker wellbeing. In doing so we focus on the private sector and use a unique linked employer-employee dataset which contains two different measures of employee wellbeing - job satisfaction and job-related anxiety - and permits us to measure workplace 'union environment' based on both employer and employee responses.

Unions are likely to have positive spill-over effects on covered non-members. On the other hand, they may have negative spill-over effects on non-members due to three potentially countervailing factors. First, unions may manage to procure private goods exclusively for their members. Such 'discrimination' on the part of unions - with the collusion of employers - may trigger job dissatisfaction on the part of non-members. Secondly, the operation of union bargaining and voice may adversely impact the wellbeing of non-members. Such workers may be disproportionately negatively affected by voice induced complaining by union members in the bargaining process. Union members strive to strengthen their bargaining power through engaging in the bargaining process, a process that excludes non-members. However, the atmosphere this process creates, particularly if it is conflict-laden, may lead to a negative externality of union behaviour on the wellbeing of non-members. Third, it may be that nonmembers are 'different' from members on potentially unobservable dimensions such that they have some distaste for unionisation. Given these, it would not be unreasonable to expect a 
causal effect of unionization on the wellbeing of non-members. On the other hand, the net spillover effect would be an empirical question.

In this paper we find that being in a union workplace and having union co-workers affect the job satisfaction of non-union employees negatively, but they are not related to nonunion employees' job-related anxiety. Job satisfaction entails perceptions of wellbeing relative to some reference point - such as co-workers - whereas job-related anxiety does not. So the fact that union effects are confined to job satisfaction suggests the unionisation of non-members' coworkers operates through the comparisons non-members make with members with respect to aspects of their job.

The rest of the paper is organised as follows. Section 2, makes a review of the relevant literature. In section 3, a detailed account of the data and variables used in the empirical analyses will be provided. Section 4 sets out the framework for the empirical analysis undertaken. Section 5 discusses the empirical results obtained before the final section concludes the paper.

\section{Review of the literature}

The negative association between job satisfaction and union membership is a puzzling empirical regularity. The puzzle stems from the expectation that unions should in general enhance members' job satisfaction and wellbeing. A number of influential studies have established the link between unions and levels of pay either in terms of a direct premium attributable to unions or through reducing pay inequality (see, for example, Freeman 1980, Booth 1995, Gosling and Machin 1995, Clark and Oswald 1996, Card 1996, Card et al. 2003, Budd and Na 2000, Metcalf et al. 2001, Hirsch 2004, Blanchflower and Bryson 2004). Aside from their effect on pay, unions have also been linked to a number of other welfare improving changes for members, which include access to employer provided training (Booth 1991, Acemoglu et al. 2001, Booth et al. 2003, Waddoups 2012), risk sharing (Malcomson 1983), health insurance and pension plans (Buchmueller et al. 2002), workplace and occupational health and safety (Donado and Walde 2012), family friendly policies (Budd and Mumford 2004), and curbing discrimination (Phanindra and Peled 1999). More generally unions uphold members' interest in collective bargaining on issues such as transfers, promotions and grievances, among others, in the spirit of Freeman and Medoff (1984)'s "collective voice".

Notwithstanding these well-established benefits associated with membership, which would be expected to enhance the satisfaction and wellbeing of members, the empirical evidence points to a negative association between membership and job satisfaction. The two competing explanations often used to justify this puzzle are the 'sorting' and 'voice' hypotheses. The 
'sorting' hypothesis attributes member dissatisfaction to either the characteristics of unionized workers themselves or to poor working conditions in unionised work environments: either unions attract inherently dissatisfied workers or union jobs are genuinely worse, prompting workers to join forces to confront poor working conditions collectively. These are both thought to lead to spurious correlation between membership and satisfaction (Schwochau 1987, Bender and Sloane 1998, Bryson et al. 2004, Bryson et al. 2010, Green and Heywood 2010). The implication is that if the analyst is able to account fully for worker sorting, union status would not be associated with dissatisfaction. Bryson et al. (2004) argue precisely this in their paper which found no relationship between union membership and job satisfaction having accounted for worker sorting.

The 'voice' hypothesis, on the other hand, attributes the dissatisfaction of members to unions' prompting employees to express their grievances collectively (Freeman and Medoff 1984) or through promoting a mood of complaint with the ultimate goal of enhancing their bargaining power (Borjas 1979, Davis-Blake and Pfeffer 1990, Gordon and Denisi 1995, Bryson et al. 2010). Thus members' dissatisfaction may not reflect genuine satisfaction, but rather a manifestation of their strategic goal to enhance bargaining power. If this is the case, unionisation engenders dissatisfaction such that it will remain even after accounting for worker sorting.

Most of this literature concentrates on the impact of unionisation on union members. Little time is spent considering the effects unions and union members may have on nonmembers. The proximity of large numbers of union members might matter to non-members if members and non-members differ in their tastes and preferences. There is a large literature indicating that worker heterogeneity within a workplace is associated with adverse effects on worker wellbeing (for example, Haile 2012). Non-members' tastes may differ from members', particularly with respect to unionisation - after all, non-members have chosen not to belong to a trade union. Although this may initially arise through worker sorting, it may nevertheless generate job dissatisfaction in a causal sense. For example, Abowd and Farber's (1982) model suggests those non-union workers with high earnings potential who end up in union workplaces are misallocated and will have a preference for greater wage inequality than members, such that the wage standardising policies of unions will adversely affect those non-members' wellbeing.

Unionisation may also affect non-members irrespective of non-members' proximity to members due to the spill-over effects of union bargaining and voice onto non-union workers. For instance, non-members may be disproportionately negatively affected by members' voice induced complaining in the bargaining process. This will occur if members are prepared to complain to strengthen their bargaining power whereas non-members, who are outside the 
bargaining process, experience the more conflict-laden atmosphere as a negative externality of union behaviour. It is also possible that unions, who are keen to procure private excludable goods for their union members, are able to promote policies that discriminate in favour of union members, perhaps with the collusion of employers, generating job dissatisfaction on the part of non-union workers. The counter-argument is that unions are rarely able to procure private excludable goods while employers are prevented in law from discriminating on grounds of union membership. Instead, unions tend to provide public goods thus extending the benefits they confer on members to their non-member covered counterparts. Donado and Walde (2012) show this to be the case with respect to health and safety at work. Other things equal, this might translate into higher levels of non-member wellbeing than they might have had in a non-union environment.

This paper introduces an innovative approach, which departs from the traditional approach of focusing on differences in job satisfaction between union and non-union workers. The approach involves comparing the job satisfaction (and job-related anxiety) of non-union workers in union jobs with that of their counterparts in non-union jobs. As well as comparing the two groups of non-union workers indiscriminately, which may be susceptible to the problem of selection bias, the paper also implements the method of matching to compare non-union workers in union jobs with their counterparts in non-union jobs. The matching approach controls for selection on observable characteristics of non-union workers allowing 'like-for-like' comparison.

\section{Data and variables}

\subsection{Overview of the Data}

The data used in this paper come from the 2004 British Workplace Employment Relations Survey (WERS2004), the most authoritative source of information on employment relations in Great Britain. It offers linked employer-employee data representative of all workplaces with five or more employees (Kersley et al. 2006). The survey covers a whole host of issues relating to both employers and employees, allowing control on a range of individual- and workplace-level attributes. The estimation sample used in this paper is confined to private sector establishments and comprises 12150 employees in 1058 workplaces. This is obtained after the elimination of: ( $i$ ) missing values in any one of the reported wellbeing outcomes, (ii) missing values in any one of the employee and workplace covariates and (iii) retaining only workplaces with at least two responding employees. As can be seen from Table 8 in the Appendix, only 24\% of private sector employees in the final sample are union members. 


\subsection{Definition of variables}

\subsubsection{Outcome variables}

There are two types of employee wellbeing measures in WERS2004. The first relates to levels of satisfaction with eight different job facets. The survey asked employees to rate - on a five-point scale from 'very satisfied' to 'very dissatisfied' - "how satisfied are you with the following aspects of your job": (i) the sense of achievement they get from their work; (ii) the scope for using their own initiative; (iii) the amount of influence they have over their job; (iv) the training they receive; (v) the amount of pay they receive; (vi) their job security; (vir) the work itself and (viii) their involvement in decision making. Secondly, WERS2004 also monitored job-related anxiety. Employees were solicited to provide responses - on a five five-point scale from 'all of the time' to 'never' - to the question "thinking of the past few weeks, how much of the time has your job made you feel each of the following: tense, calm, relaxed, worried, uneasy, and content?”

Principal components analysis on the facets of job satisfaction identified a single factor with an eigen value above 1 (3.99) explaining 99 per cent of the variance in the eight items and with a Kaiser-Meyer-Olkin (KMO) sampling adequacy measure of 0.88. Similarly, principal components analysis on the job-related anxiety outcomes identified one factor with an eigen value above 1 (3.42) explaining 88 per cent of the variance in the six job-related anxiety measures and with a KMO sampling adequacy measure of $0.80 .{ }^{1}$ Based on the principal components analyses, therefore, two different job-related wellbeing measures have been generated - job satisfaction and job-related anxiety - for the empirical analysis conducted in this paper. To minimise the problem of endogeneity commonly associated with 'pay satisfaction' the paper excluded the domain of pay satisfaction and rely on non-pecuniary measures of satisfaction.

Reported levels of satisfaction on the remaining seven facets with 5-point scores have then been recoded into $(-2,2)$ scales, where ' -2 ' is "very dissatisfied" and '2' is "very satisfied". As can be seen from the descriptive statistics in Table 7 in the Appendix, the resulting single summative job satisfaction outcome measure runs from $(-14,14)$. Similarly, the six facets of jobrelated anxiety measures with a 5 -point score have also been rescaled into $(-2,2)$ scales, where '2 ' is "never" and ' 2 ' is "all of the time" after reverse coding the positive affect items first. The resulting summative job-related anxiety measure runs from $(-12,12) .^{2}$ Figure 1 in the Appendix depicts the additive job satisfaction and job-related anxiety outcome measures for the full private

\footnotetext{
1 The Cronbach's alpha for the eight facets of job satisfaction and the six job-related anxiety measures are 0.85 and 0.86, respectively. The Cronbach's alpha values are comparable to those reported in Wood (2008) and Bryson et al. (2009).

2 The approach used here in generating the single summative scale follows that employed in Bryson et al. (2012)
} 
sector sample by union membership status. Consistent with the wider literature, the Figure shows higher level of satisfaction for non-members. On the other hand, the observed difference in the level of job-related anxiety between members and non-members appears to be much less pronounced.

As detailed in Bryson et al. (2012), job satisfaction and job-related anxiety capture two distinct components of worker wellbeing. Psychological studies also emphasise the need for broader definition of work-related psychological well-being than just job satisfaction (Warr 1990, 1994, 1999). Job-related anxiety measures are also thought to be amongst the most important, if not the most important, measures of psychological well-being (Warr 1994, Daniels 2000). ${ }^{3}$ Taking these into account, this paper uses both job satisfaction and job-related anxiety measures in the empirical analysis undertaken. It is also worth noting that the wording of the job-related anxiety question indicates that the job anxiety measure monitors experiences of positive and negative emotional states over a shorter recall period ("the past few weeks") and may offer a more accurate reflection of emotional wellbeing vis-à-vis the job satisfaction measure. In addition, job satisfaction is likely to be influenced by one's prior expectation (of, for example, a pay rise or promotion) while the job-related anxiety measures may reflect actual feelings (of, for example, uneasiness) experienced over a short recall period, which may not be influenced by expectations as much. Taking these into account, this paper uses both job satisfaction and jobrelated anxiety measures in the empirical analysis undertaken.

\subsubsection{Measures of union 'environment' and other control variables}

The paper employs two broad measures of workplace union 'environment' depending on whether the response to the question on union status is provided by the employer or the employee. The first such measure is a dummy variable 'union workplace' which is based on employers' responses. It assumes a value 1 if the employer responded affirmatively to the question "are any employees here members of a trade union or independent staff association" and 0 otherwise. The second measure, a dummy variable 'union co-worker' is based on employees' responses. It assumes a value 1 for non-union workers in a workplace if at least one employee in the surveyed workplace responded to be a union or staff association member and 0 otherwise. The first dummy variable thus provides a measure of the wellbeing differential between union and non-union workplaces as identified by the employer. The second dummy variable, on the

\footnotetext{
3 As stated earlier, the job-related anxiety measures represent experiences of positive and negative emotional states over a short recall period ("the past few weeks") and may represent a more accurate reflection of wellbeing. In addition, job satisfaction is likely to be influenced by one's prior expectation (of, for example, a pay rise or promotion) while the job-related anxiety measures may reflect actual feelings (of, for example, uneasiness) experienced over a short recall period, which may not be influenced by expectation as much.
} 
other hand, provides a measure of the wellbeing differential between union and non-union employees as identified by the employees themselves. Unlike the first dummy variable, which does not distinguish between union and non-union workers within a union workplace, the second dummy variable allows capturing the variation between union and non-union workers within a union workplace. A number of other variables relating to employee demographic and human capital characteristics, job characteristics, industry of employment and a range of employer characteristics including geographic location and travel-to-work area unemployment and vacancy rates, have also been controlled for in the empirical analysis. Table 8 in the appendix reports descriptive statistics on all the control variables, including the two 'union environment' dummy variables described above, which have been used in the regression analysis conducted, both for the full private sector sample and by membership sub-samples.

\section{A framework of analysis}

We assume wellbeing proxies the level of utility an employee derives from their job. The arguments of the utility function include pecuniary and non-pecuniary attributes of the employee-employer match, including co-workers' and workplace's union status, which can be specified as:

$$
U_{i j}=f\left(g_{j}, \mathbf{E E}_{i j}, \mathbf{E R}_{j}\right), \quad i=1, \ldots, I \text { and } j=1, \ldots, J
$$

where $i$ and $j$ index employees and workplaces, respectively; $g$ represents the union status of the workplace and/or co-workers, EE stands for employee's demographic, human capital and job related characteristics, and ER stands for workplace characteristics that include geographic location. The corresponding empirical model estimated has the general format given in equation (2) below.

$$
W_{i j}=f\left(g_{j}, \mathbf{E E}_{i j}, \mathbf{E R}_{j}\right)+\varepsilon_{i j}, \quad i=1, \ldots, I \text { and } j=1, \ldots, J
$$

where, $W$ represents the level of self-reported wellbeing - job satisfaction and/or jobrelated anxiety that represent underlying continuous latent measures of wellbeing, $W_{i j}^{*}$. Equation (2) is estimated using OLS, separately for job satisfaction and job-related anxiety. ${ }^{4}$ The paper principally focuses on non-union (NU) workers by comparing the wellbeing of non-union

\footnotetext{
${ }^{4}$ This is done with the cluster option to account for the presence of at least two employees from same workplace.
} 
workers in workplaces with and without union co-workers. Equation (2) can thus be re-specified as:

$$
W_{i j}^{N U}=f\left(g_{j}^{N U}, \mathbf{E E}_{i j}^{N U}, \mathbf{E R}_{j}^{N U}\right)+\varepsilon_{i j}, \quad i=1, \ldots, I \text { and } j=1, \ldots, J
$$

where the superscript NU stands for non-union worker and other notations as defined in equation (2).

For reasons discussed earlier a simple comparison of the wellbeing of non-union workers in workplaces with and without union co-worker(s) may be misleading, if there is employee and/or employer sorting into union jobs. To the extent that sorting occurs, estimates obtained from equation (3) can be biased. To address this, the paper also implements a matching estimator (Rosenbaum and Rubin 1983). Let $W^{1}$ and $W^{0}$ represent the wellbeing outcomes of non-union worker(s) in union and non-union workplaces, respectively. We define 'treatment' as non-union workers having at least one union member co-worker(s) $(\mathrm{D}=1)$ as opposed to not having one $(D=0)$. We seek to recover the causal effect of working in union workplaces on the wellbeing of non-union workers by matching non-members to the non-member sample to obtain the average treatment effect on the treated (ATT). The Conditional Independence Assumption (CIA) can be invoked to generate the counterfactual wellbeing outcome of being in a non-union workplace using the method of matching as:

$$
E\left(W^{0} \mid D=1, P(X)\right)=E\left(W^{0} \mid D=0, P(X)\right)
$$

where $P($.$) denote the probability scores of being a non-union employee in a union job,$ which are estimated on a rich set of employee and employer characteristics, $X$, contained in the linked WERS2004 data. ${ }^{5}$ Matching allows constructing the comparison group of employees in non-union workplaces who resemble non-union employees in union workplaces. Under CIA, the average wellbeing effect of being in union workplaces on non-union workers (ATT) can be retrieved as:

\footnotetext{
5 The matching estimator assumes the outcomes of interest (here wellbeing) are independent of participation status conditional on a set of observable characteristics (Heckman, Ichimura, and Todd 1998). It is thus vital that only exogenous variables liable to affect both 'treatment' and outcomes are used, excluding potentially endogenous variables. In view of this, the controls used for the matching equation in this paper exclude workplace size, workplace industry, whether union is encouraged at the workplace, level of union coverage, and individual union membership status, which are likely to be endogenous.
} 


$$
\frac{1}{N^{1}} \sum_{i^{1} \in\{D=1\}}\left(\left(W^{1}\right)_{i^{1}}-\sum_{i^{0} \in\{D=0\}} w_{i i^{i} i^{0}}\left(W^{0}\right)_{i^{0}}\right)
$$

where $\left(W^{1}\right)_{i^{1}}$ is the wellbeing outcome of the $i^{1}$ th non-union employee in union workplaces $\left(i^{1} \in\{D=1\}\right),\left(W^{0}\right)_{i^{0}}$ is the wellbeing outcome of the $i^{0}$ th employee in non-union workplaces $\left(i^{0} \in\{D=0\}\right), w_{i^{1} i^{0}}$ is the weight of employees from non-union workplaces with $\sum_{i^{0} \in\{D=0\}} w_{i i^{i}}=1$ and $N^{1}$ is the number of non-union workers in union workplaces $i^{1}$. The counterfactual outcome is estimated using the weight function $w_{i^{1} i^{0}}$ in the sample of employees in non-union workplaces, $i^{0}$, relative to the predicted propensity score $\widehat{P(X)}$ of each 'treated' non-union employee $i^{1}$. The matching method used in this paper is gaussian kernel matching with common support. It is implemented on propensity scores estimated using probit models, which estimated the probability of being a non-union employee in a union workplace. Thus, employees from non-union workplaces (the 'control' group) get weights according to their distance from non-union workers in union workplaces (the 'treated' group) based on estimated propensity scores, with larger weights assigned to employees from non-union workplaces that are 'close' to non-union employees in union workplaces on the basis of these scores. Table 5 in the Appendix reports coefficient estimates from the probit equations estimated, which controls for extensive set of employer and employee characteristics thought to determine employment in a union workplace and having union co-worker(s). Propensity scores from these probit models, which indicate a large common support, have been used to perform the matching. Table 6 in the Appendix reports covariate imbalance test results, which suggest a good quality match.

It is however worth noting that the matching estimator controls for selection on observable characteristics. As such it does not address potential selection on unobservables that may underlay at least some of the employer-employee sorting. Nonetheless, we are using linked employer-employee data that contain a rich set of covariates affecting both treatment and outcome, thus lending credibility to the CIA.

\section{Results and discussion}

Estimation results from the empirical analysis conducted are reported in Tables 1 to 4 in the Appendix. All the estimation results reported use survey weights and also account for clustering at the workplace level, since there are at least two employees from each workplace in 
the estimation sample. ${ }^{6}$ The results in Tables 1 and 2 are based on the full private sector sample, which includes both union and non-union employees, while those in Tables 3 and 4 are for nonunion employees only. The regression results in Tables 1 to 3 show three different specifications in each case: without controls, with employee-level controls and with both employee- and employer-level controls.

Table 1 reports regression results relating to the job satisfaction outcome measure for the full sample. The results suggest a negative and statistically significant effect of being in a union workplace on job satisfaction. This suggests a reduction in job satisfaction in union workplaces after controlling for a battery of employee and employer characteristics, which include individual membership status and workplace union coverage. The coefficient of the individual union membership variable is negative and statistically significant, which is consistent with the empirical 'puzzle' identified in the literature. The negative effect linked to the union status of the workplace this paper finds is thus on top of the empirical 'puzzle' the literature identifies. Employee union membership status based sub-group analysis reveals the negative link between job satisfaction and workplace union status holds for union and non-union employees alike. However, the estimated effects for the union and non-union sub-samples are not significantly different from one another except in the first specification. In terms of magnitude, the estimated effects for the full sample suggest between 0.15 and 0.07 standard deviations decline in job satisfaction for a 1 standard deviation increase in workplace union status. Table 2 reports regression results relating to the job-related anxiety outcome for the full sample. Except for the simplest specification with no controls, no statistically significant effect is found. None of the estimated sub-group-related effects are also significantly different from one another.

Table 3 reports results relating to the effect of union co-worker(s), as identified from employees' response, on job satisfaction and job-related anxiety. All specifications of the job satisfaction equation reveal statistically significant negative effect of having a union co-worker(s) on job satisfaction. This suggests that non-union workers in workplaces where there are union co-workers experience a reduction in job satisfaction. The magnitude of the negative link suggests a 1 standard deviation increase in co-workers' union status resulting in a reduction in job satisfaction of between 0.07 and 0.05 standard deviations. In contrast, none of the estimated effects of the job-related anxiety equation reveal a statistically significant link with the union status of co-worker(s).

\footnotetext{
${ }^{6}$ For the matching estimator, the propensity scores from the probit equations estimated use sampling weights and account for clustering. As noted in the preceding section, the kernel weights signify the distance of employees in non-union workplaces ('controls') from non-union employees in union workplaces (the 'treated') in terms of the estimated probability scores.
} 
As noted in Section 4, we also implement the alternative matching estimator. The semiparametric matching estimator, which enforces common support, compares non-union employees in union and non-union workplaces who are observationally similar. Matching is performed on propensity scores obtained from probit regressions that estimate probabilities of (a) being in a union workplace and (b) having a union co-worker, which are reported in Table 5. Table 4 reports results from the matching estimator for both measures of workplace 'union environment', which provide the average wellbeing effect of: (a) being in a union workplace, defined based on the employer response, and (b) having union co-worker(s), defined based on employee response, on the job satisfaction (or job-related anxiety) of non-union workers (ATT). Standard errors are bootstrap standard errors which take into account sampling variability in the estimated propensity scores. ${ }^{7}$ As can be seen from the ATT estimates, being in a union workplace and having union co-worker(s) are both found to have statistically significant negative effect on the job satisfaction of non-union workers. In terms of magnitude, a 1 standard deviation increase in union workplace and union co-worker(s) results in a .07 and .05 decline in the job satisfaction of non-union employees in union workplaces, respectively.

As in the results reported in Tables 2 and 3, the results in Table 4 do not reveal statistically significant link between workplace union 'environment' and job-related anxiety. As noted in Section 3, the job-related anxiety measure captures experiences of positive and negative emotional states over a short recall period in contrast to the job satisfaction measure, which does not make a particular reference to time period. More importantly, the level of one's job satisfaction is likely to be influenced by one's prior expectation. The level of one's job-related anxiety, on the other hand, may reflect actual feelings (of, for example, uneasiness) experienced over a short recall period, which may not be influenced by expectations as much. It may therefore be that the workplace union environment does not have much bearing on such emotional states.

\section{Conclusion}

This paper examined the question of whether there is a link between workplace 'union environment' and employee wellbeing using linked employer-employee data. Union environment is defined in terms of the union status of workplaces and co-worker(s); while employee wellbeing constitutes reported levels of job satisfaction and job-related anxiety. We employed an innovative approach that departed from the standard approach in the union literature by

\footnotetext{
${ }^{7}$ Bootstrapping has been implemented with 250 replications.
} 
comparing the wellbeing of non-union workers who work with union co-workers and those who do not.

The paper made important contribution to the literature by revealing the negative link between workplace 'union environment' - defined in terms of the union status of a workplace or of co-worker(s) - and job satisfaction. This effect is over and above the empirical 'puzzle' the literature identifies regarding the link between individual membership status and job satisfaction. On the other hand, we do not find any link between the workplace 'union environment' and job-related anxiety. Membership status based sub-group analysis provides some evidence that the negative effect of workplace union status on job satisfaction is limited to non-union workers. Further investigation confined to non-union employees revealed this effect to be specific to non-union employees in union workplaces.

The findings in the paper thus lend some support to the 'sorting' hypothesis. As noted in Section 2, the sorting explanation suggests either: (a) that unions are not associated with dissatisfaction or (b) that non-union workers would also be dissatisfied at union jobs, if it is the jobs that are genuinely worse. Using an innovative approach and a rich linked employeremployee data, this paper has demonstrated the latter to be the case. On the other hand, the paper does not find any link between union status and job-related anxiety, something the raw data also show. This may be due to job-related anxiety capturing experiences of positive and negative emotional states over a short recall period, in contrast to job satisfaction which captures perceptions of wellbeing relative to some reference point such as co-workers. So the fact that union effects are confined to job satisfaction suggests the unionisation of non-members' coworkers operates through the comparisons non-members make with members with respect to aspects of their job. 


\section{References}

Abowd, J. and Farber, H. (1982) Job queues and the union status of workers, Industrial and Labor Relations Review, 35 (3), 354-367.

Acemoglu, D., Aghion, P. and Violante, G. (2001) Deunionization, Technical Change and Inequality, Carnegie-Rochester Conference Series on Public Policy, 55, 229-264.

Ashenfelter, O. and Johnson, G. (1969) Bargaining Theory, Trade Unions, and Industrial Strike Activity, The American Economic Review, 59 (1): 35-49.

Bender, K. and Sloane, P. (1998) Job satisfaction, trade unions, and exit-voice revisited, Industrial and Labor Relations Review, 51, 222-240.

Blanchflower, D. and Bryson,A. (2004) Union relative wage effects in the United States and the United Kingdom, Proceedings of the 56th Annual Meeting of the Industrial Relations Research Association, Champaign, IL, pp. 133-140.

Booth, A. (1991) Job-Related Formal Training: Who Receives It and What Is It Worth? Oxford Bulletin of Economics and Statistics, 53 (3), 281-94.

Booth, A. and Chatterji, M. (1995) Union Membership and Wage Bargaining when Membership is not Compulsory, The Economic Journal, 105 (429), 345-360.

Booth, A., Francesconi, M. and Zoega, G. (2003) Unions, Work-Related Training, and Wages: Evidence for British Men, Industrial and Labor Relations Review, 57 (1), 68 - 91.

Borjas, G. (1979) Job satisfaction, wages and unions, The Journal of Human Resources, 14, 21-40.

Bryson, A., Barth, E., and Dale-Olsen, H. (2012) Do higher wages come at a price? Journal of Economic Psychology, 33, 251-263

Bryson, A., Cappellari, L. and Lucifora, C. (2004) Does union membership really reduce job satisfaction? British Journal of Industrial Relations, 42, 439-459.

Bryson, A., Cappellari, L. and Lucifora, C. (2010) Why So Unhappy? The Effects of Unionization on Job Satisfaction, Oxford Bulletin of Economics and Statistics, 72 (3): $357-$ 380.

Bryson, A., Barth, E. and Dale-Olsen, H. (2012), Do higher wages come at a price? Journal of Economic Psychology, 33, 251-263.

Bryson, A., Dale-Olsen, H. and Barth, E. (2009), How Does Innovation Affect Worker wellbeing? CEP Discussion Paper No 953, LSE.

Buchmueller, T., Dinardo, J. and Valletta, G. (2002) Union Effects on Health Insurance Provision and Coverage in the United States, Industrial and Labor Relations Review, 55 (610).

Budd, J. and Mumford, K. (2004) Trade Unions and Family Friendly Policies in Great Britain, Industrial and Labor Relations Review, 57 (204).

Budd, J. and Na, I. (2000) The Union Membership Wage Premium for Employees Covered by Collective Bargaining Agreements, Journal of Labor Economics, 18 (4), 783-807.

Card, D. (1996) The Effect of Unions on the Structure of Wages: A Longitudinal Analysis, Econometrica, 64 (4), 957-979.

Card, D., Lemieux, T. and Riddell, W. C. (2003) Unionization and Wage Inequality: A Comparative Study of the U.S., the U.K. and Canada, National Bureau of Economic Research Working Paper, No. W9473.

Clark, A. and Oswald, A. (1996) Satisfaction and comparison income, Joumal of Public Economics, 61, 359-381.

Daniels, K (2000), Measures of five aspects of affective well-being at work, Human Relations, 53 (2), $275-294$.

Davis-Blake, A. and Pfeffer, J. (1990) Unions and job satisfaction: an alternative view, Work and Occupations, 17, 259-283.

Donado, A. and Walde, K. (2012), How Trade Unions Increase Welfare, Economic Journal, Published Online on 09 March 2012, DOI: 10.1111/j.1468-0297.2012.02513.x 
Freeman, R. (1980) Unionism and the dispersion of wages, Industrial and Labor Relations Review, 34 (1), 3-23.

Freeman, R. and Medoff, J. (1984) What do Unions Do? Basic Books, New York.

Gordon, M. and Denisi, A. (1995) Are-examination of the relationship between union membership and job satisfaction, Industrial and Labor Relations Review, 48, 222-236.

Gosling, A. and Machin, S. (1995) Trade Unions and the Dispersion of Earnings in British Establishments 1980-90, Oxford Bulletin of Economics and Statistics, 57(2), 167-84.

Green, C. and Heywood, S. J. (2010) Unions, Dissatisfied Workers and Sorting. (Economics Working Paper Series). Lancaster University: The Department of Economics.

Haile, G. (2012) Unhappy working with men? Workplace gender diversity and employee wellbeing in Britain, Labour Economics, 19, 329-350.

Heckman, J., Ichimura, H. and Todd, P. (1998) Matching as an Econometric Evaluation Estimator, Review of Economic Studies, 65, 261-294.

Hirsch, B. (2004) Reconsidering Wage Effects; Surveying New Evidence on an Old Topic, Journal of Labor Research, 25 (2), 233-66.

Kersley, B., Alpin, C., Forth, J., Bryson, A., Bewley, H., Dix, G. and Oxenbridge, S. (2006). Inside the Workplace: Findings from the 2004 Workplace Employment Relations Survey, Routledge, London.

Leuven, E. and Sianesi, B. (2003) PSMATCH2: Stata module to perform full Mahalanobis and propensity score matching, common support graphing, and covariate imbalance testing, http://ideas.repec.org/c/boc/bocode/s432001.html. This version: 2012.

Malcomson, J. (1983) Trade Unions and Economic Efficiency, Economic Journal, 93, 51-65.

Metcalf, D. , Hansen, K. and Charlwood, A. (2001) Unions and the Sword of Justice: Unions and pay systems, pay inequality, pay discrimination and low pay, National Institute Economic Review, 176, 61-75

Rosenbaum, P. and Rubin, D.B. (1983) The Central Role of the Propensity Score in Observational Studies for Causal Effects, Biometrika, 70, 41-55.

Schwochau, S. (1987) Union effects on job attitudes, Industrial and Labor Relations Review, 40, 209224.

Waddoups, C. (2012) Union Membership and Job-Related Training: Incidence, Transferability, and Efficacy, British Journal of Industrial Relations, DOI:10.1111/j.1467-8543.2012.00909.x

Warr, P. (1990), The Measurement of Well-being and Other Aspects of Mental Health, Journal of Occupational Psychology, 63 (3), 193 - 210.

Warr, P. (1994), Conceptual framework for the study of work and mental health, Work and Stress, $8,84-97$.

Warr, P. (1999), Well-being and the Workplace, in Kahneman, D., Diener, E. and Schwarz, N. (eds.), Well-being: the foundations of hedonic psychology, Russell Sage Foundation, New York.

Wood, S. (2008) Job characteristics, employee voice and well-being in Britain, Industrial Relations Journal, 39 (2), $153-168$.

Wunnava, P. and Peled, N. (1999) Union Wage Premium by Gender and Race: Evidence from PSID 1980-1992, Journal of Labor Research, 20 (3), 415-423. 
Appendix: Regression outputs and descriptive statistics

Table 1: Workplace union status and job satisfaction, union and non-union employees, employer response based.

\begin{tabular}{|c|c|c|c|c|c|c|c|c|c|}
\hline & \multicolumn{9}{|c|}{ Job satisfaction } \\
\hline & $\begin{array}{l}\text { Full } \\
\text { sample }\end{array}$ & $\begin{array}{l}\text { Union } \\
\text { members }\end{array}$ & $\begin{array}{l}\text { Non- } \\
\text { members }\end{array}$ & $\begin{array}{l}\text { Full } \\
\text { sample }\end{array}$ & $\begin{array}{l}\text { Union } \\
\text { members }\end{array}$ & $\begin{array}{l}\text { Non- } \\
\text { members }\end{array}$ & $\begin{array}{l}\text { Full } \\
\text { sample }\end{array}$ & $\begin{array}{l}\text { Union } \\
\text { members }\end{array}$ & $\begin{array}{l}\text { Non- } \\
\text { members }\end{array}$ \\
\hline \multirow[t]{2}{*}{ Union workplace } & $-1.566 * * *$ & $-1.878^{* * *}$ & $-1.055 * * *$ & $-0.998 * * *$ & $-1.287 * * *$ & $-0.959 * * *$ & $-0.698 * * *$ & -0.492 & $-0.724 * * *$ \\
\hline & $(0.182)$ & $(0.493)$ & (0.198) & $(0.184)$ & $(0.466)$ & $(0.190)$ & $(0.214)$ & $(0.540)$ & $(0.224)$ \\
\hline \multirow[t]{2}{*}{ Age $<30$} & & & & -0.114 & 0.356 & -0.165 & 0.075 & 0.566 & -0.008 \\
\hline & & & & $(0.167)$ & $(0.407)$ & $(0.187)$ & $(0.166)$ & $(0.408)$ & $(0.185)$ \\
\hline \multirow[t]{2}{*}{ Age30-39 } & & & & -0.038 & 0.075 & -0.060 & 0.073 & 0.219 & 0.034 \\
\hline & & & & $(0.155)$ & $(0.327)$ & $(0.184)$ & $(0.152)$ & $(0.297)$ & $(0.181)$ \\
\hline \multirow[t]{2}{*}{ Age50+ } & & & & $0.743 * * *$ & $1.280^{* * *}$ & $0.582^{* * *}$ & $0.623 * * *$ & $1.053 * * *$ & $0.496 * * *$ \\
\hline & & & & $(0.167)$ & $(0.332)$ & $(0.193)$ & $(0.164)$ & $(0.330)$ & $(0.190)$ \\
\hline \multirow[t]{2}{*}{ Female } & & & & $0.405^{* * *}$ & $1.113^{* * *}$ & 0.244 & $0.232^{*}$ & $0.745^{* *}$ & 0.125 \\
\hline & & & & $(0.135)$ & $(0.337)$ & $(0.149)$ & $(0.135)$ & $(0.358)$ & $(0.148)$ \\
\hline \multirow[t]{2}{*}{ Married } & & & & $0.348^{* * *}$ & -0.003 & $0.448^{* * *}$ & $0.340 * * *$ & 0.052 & $0.414^{* * *}$ \\
\hline & & & & $(0.131)$ & $(0.303)$ & $(0.144)$ & $(0.129)$ & $(0.300)$ & $(0.142)$ \\
\hline \multirow[t]{2}{*}{ White } & & & & -0.171 & -0.613 & -0.107 & -0.304 & -0.715 & -0.253 \\
\hline & & & & $(0.349)$ & $(0.625)$ & $(0.391)$ & $(0.366)$ & $(0.633)$ & $(0.412)$ \\
\hline \multirow[t]{2}{*}{ Children $<7$ yrs old } & & & & -0.025 & 0.205 & -0.101 & -0.087 & 0.304 & -0.189 \\
\hline & & & & $(0.171)$ & $(0.348)$ & $(0.195)$ & $(0.162)$ & $(0.332)$ & $(0.183)$ \\
\hline \multirow[t]{2}{*}{ Other dependents } & & & & $-0.320 * *$ & $-0.712^{* *}$ & -0.187 & $-0.394 * *$ & $-0.655^{* *}$ & -0.295 \\
\hline & & & & $(0.160)$ & $(0.286)$ & $(0.189)$ & $(0.156)$ & $(0.283)$ & $(0.183)$ \\
\hline \multirow[t]{2}{*}{ Disabled } & & & & $-0.547 * * *$ & $-0.869 * *$ & $-0.446 * *$ & $-0.528^{* * *}$ & $-0.797 * *$ & $-0.417 * *$ \\
\hline & & & & $(0.192)$ & $(0.385)$ & $(0.219)$ & $(0.187)$ & $(0.388)$ & $(0.213)$ \\
\hline \multirow[t]{2}{*}{ No academic qualification } & & & & $0.704 * * *$ & $1.288^{* * *}$ & $0.598^{* *}$ & $0.754 * * *$ & $1.580 * * *$ & $0.570 * *$ \\
\hline & & & & $(0.245)$ & $(0.474)$ & $(0.284)$ & $(0.236)$ & $(0.454)$ & $(0.271)$ \\
\hline \multirow[t]{2}{*}{ O-level } & & & & $0.577 * * *$ & $0.833^{*}$ & $0.550 * *$ & $0.567 * * *$ & $0.958 * *$ & $0.486 * *$ \\
\hline & & & & $(0.206)$ & $(0.426)$ & $(0.220)$ & $(0.197)$ & $(0.413)$ & $(0.214)$ \\
\hline \multirow[t]{2}{*}{ A-level } & & & & 0.336 & 0.442 & 0.307 & $0.418^{*}$ & 0.763 & 0.330 \\
\hline & & & & $(0.220)$ & $(0.547)$ & $(0.240)$ & $(0.215)$ & $(0.549)$ & $(0.233)$ \\
\hline \multirow[t]{2}{*}{ Other qualification } & & & & $0.313^{*}$ & $0.873^{* *}$ & 0.209 & 0.257 & $0.936 * *$ & 0.114 \\
\hline & & & & $(0.189)$ & $(0.393)$ & $(0.204)$ & $(0.183)$ & $(0.388)$ & $(0.198)$ \\
\hline On permanent contract & & & & $1.035^{* * *}$ & 0.417 & $1.132^{* * *}$ & $1.265^{* * *}$ & 0.833 & $1.334 * * *$ \\
\hline
\end{tabular}




\begin{tabular}{|c|c|c|c|c|c|c|}
\hline & $(0.231)$ & $(0.587)$ & $(0.250)$ & $(0.230)$ & $(0.614)$ & $(0.246)$ \\
\hline \multirow[t]{2}{*}{ Full-time } & -0.272 & -0.077 & -0.281 & -0.167 & -0.078 & -0.165 \\
\hline & $(0.198)$ & $(0.407)$ & $(0.219)$ & $(0.187)$ & $(0.401)$ & $(0.208)$ \\
\hline \multirow[t]{2}{*}{ Works over 48 hours } & $0.322 * *$ & $0.728 * *$ & 0.203 & 0.190 & $0.561 * *$ & 0.102 \\
\hline & $(0.139)$ & $(0.295)$ & $(0.158)$ & $(0.134)$ & $(0.271)$ & $(0.154)$ \\
\hline \multirow[t]{2}{*}{ Skill same as required } & $1.474 * * *$ & $1.717 * * *$ & $1.412^{* * *}$ & $1.396^{* * *}$ & $1.584^{* * *}$ & $1.356^{* * *}$ \\
\hline & $(0.110)$ & $(0.231)$ & $(0.123)$ & $(0.108)$ & $(0.220)$ & $(0.121)$ \\
\hline \multirow[t]{2}{*}{ Professional } & $-1.918^{* * *}$ & $-1.785^{* * *}$ & $-1.992 * * *$ & $-1.832^{* * *}$ & $-2.384 * * *$ & $-1.736 * * *$ \\
\hline & $(0.272)$ & $(0.598)$ & $(0.301)$ & $(0.289)$ & $(0.690)$ & $(0.312)$ \\
\hline \multirow[t]{2}{*}{ Associate professional \& technical } & $-1.426 * * *$ & $-0.959 *$ & $-1.603 * * *$ & $-1.438 * * *$ & $-1.256 * *$ & $-1.549 * * *$ \\
\hline & $(0.225)$ & $(0.536)$ & $(0.239)$ & $(0.224)$ & $(0.546)$ & $(0.230)$ \\
\hline \multirow[t]{2}{*}{ Admin. \& secretarial } & $-1.894 * * *$ & $-2.096 * * *$ & $-1.841 * * *$ & $-1.687 * * *$ & $-1.793 * * *$ & $-1.656^{* * *}$ \\
\hline & $(0.231)$ & $(0.526)$ & $(0.248)$ & $(0.225)$ & $(0.527)$ & $(0.239)$ \\
\hline \multirow[t]{2}{*}{ Skilled trades plant \& mach. } & $-2.306 * * *$ & $-3.153 * * *$ & $-1.982 * * *$ & $-2.207 * * *$ & $-2.906 * * *$ & $-1.958 * * *$ \\
\hline & $(0.222)$ & $(0.507)$ & $(0.258)$ & $(0.213)$ & $(0.489)$ & $(0.248)$ \\
\hline \multirow[t]{2}{*}{ Personal \& customer services } & $-1.478^{* * *}$ & $-2.567 * * *$ & $-1.273^{* * *}$ & $-1.658 * * *$ & $-2.708 * * *$ & $-1.461 * * *$ \\
\hline & $(0.240)$ & $(0.560)$ & $(0.251)$ & $(0.233)$ & $(0.563)$ & $(0.244)$ \\
\hline \multirow[t]{2}{*}{ Elementary occupations } & $-1.762 * * *$ & $-2.250 * * *$ & $-1.623 * * *$ & $-1.682^{* * *}$ & $-2.084 * * *$ & $-1.566^{* * *}$ \\
\hline & $(0.287)$ & $(0.596)$ & $(0.317)$ & $(0.283)$ & $(0.595)$ & $(0.311)$ \\
\hline \multirow[t]{2}{*}{ Trade union member } & $-0.958 * * *$ & & & $-0.742 * * *$ & & \\
\hline & $(0.179)$ & & & $(0.170)$ & & \\
\hline \multirow[t]{2}{*}{ Gross weekly pay $<=110$} & $0.642^{* *}$ & 0.696 & $0.637 * *$ & $0.551 * *$ & 0.328 & $0.572 *$ \\
\hline & $(0.285)$ & $(0.661)$ & $(0.305)$ & $(0.273)$ & $(0.652)$ & $(0.295)$ \\
\hline \multirow[t]{2}{*}{ Gross weekly pay $111-180$} & 0.272 & $0.966^{*}$ & 0.162 & 0.127 & 0.772 & 0.043 \\
\hline & $(0.257)$ & $(0.550)$ & $(0.276)$ & $(0.253)$ & $(0.541)$ & $(0.274)$ \\
\hline \multirow[t]{2}{*}{ Gross weekly pay $261-360$} & $-0.369 *$ & $-0.734 *$ & -0.260 & -0.252 & -0.635 & -0.133 \\
\hline & $(0.193)$ & $(0.406)$ & $(0.216)$ & $(0.190)$ & $(0.415)$ & $(0.214)$ \\
\hline \multirow[t]{2}{*}{ Gross weekly pay 361p } & -0.087 & 0.102 & -0.082 & 0.246 & 0.331 & 0.281 \\
\hline & $(0.209)$ & $(0.423)$ & $(0.240)$ & $(0.205)$ & $(0.442)$ & $(0.234)$ \\
\hline \multirow[t]{2}{*}{ Covered } & & & & $-0.553 * *$ & $-1.199 * * *$ & -0.308 \\
\hline & & & & $(0.234)$ & $(0.448)$ & $(0.243)$ \\
\hline \multirow[t]{2}{*}{ Union membership encouraged } & & & & $0.487 * *$ & 0.502 & $0.472 *$ \\
\hline & & & & $(0.245)$ & $(0.356)$ & $(0.280)$ \\
\hline \multirow[t]{2}{*}{ More than one union present } & & & & 0.615 & 0.896 & 0.605 \\
\hline & & & & $(0.435)$ & $(0.607)$ & $(0.683)$ \\
\hline Log workplace age & & & & -0.112 & -0.015 & $-0.138^{*}$ \\
\hline
\end{tabular}




\begin{tabular}{|c|c|c|c|c|c|c|c|c|c|}
\hline & & & & & & & $(0.075)$ & $(0.127)$ & $(0.082)$ \\
\hline \multirow[t]{2}{*}{ Sole establishment } & & & & & & & $0.837 * * *$ & $0.694^{*}$ & $0.831 * * *$ \\
\hline & & & & & & & $(0.179)$ & $(0.395)$ & $(0.184)$ \\
\hline \multirow{2}{*}{ No. of employees /1000 } & & & & & & & $-0.242^{* *}$ & -0.034 & $-0.400 * * *$ \\
\hline & & & & & & & $(0.101)$ & $(0.135)$ & $(0.134)$ \\
\hline \multirow[t]{2}{*}{ Manufacturing } & & & & & & & 0.068 & 0.150 & 0.018 \\
\hline & & & & & & & $(0.270)$ & $(0.496)$ & $(0.291)$ \\
\hline \multirow{2}{*}{ Construction } & & & & & & & $1.414^{* * *}$ & 0.939 & $1.363 * * *$ \\
\hline & & & & & & & $(0.343)$ & $(0.692)$ & $(0.373)$ \\
\hline \multirow[t]{2}{*}{ Wholesale \& retail trade } & & & & & & & $0.976^{* * *}$ & $1.350 * *$ & $0.876^{* * *}$ \\
\hline & & & & & & & $(0.242)$ & $(0.582)$ & $(0.255)$ \\
\hline \multirow[t]{2}{*}{ Hotel and restaurant } & & & & & & & $0.687^{* *}$ & 0.736 & $0.685^{*}$ \\
\hline & & & & & & & $(0.315)$ & $(0.539)$ & $(0.356)$ \\
\hline \multirow[t]{2}{*}{ Public \& community services } & & & & & & & $1.079 * * *$ & 1.010 & $1.114^{* * *}$ \\
\hline & & & & & & & $(0.364)$ & $(0.634)$ & $(0.423)$ \\
\hline \multirow[t]{2}{*}{ Education } & & & & & & & $2.167 * * *$ & $1.992^{* * *}$ & $2.215^{* * *}$ \\
\hline & & & & & & & $(0.437)$ & $(0.748)$ & $(0.546)$ \\
\hline \multirow[t]{2}{*}{ Health } & & & & & & & $2.317 * * *$ & $2.069 * * *$ & $2.264^{* * *}$ \\
\hline & & & & & & & $(0.295)$ & $(0.776)$ & $(0.300)$ \\
\hline \multirow[t]{2}{*}{ Urban area } & & & & & & & -0.162 & 0.147 & -0.245 \\
\hline & & & & & & & $(0.208)$ & $(0.366)$ & $(0.221)$ \\
\hline \multirow[t]{2}{*}{ Unemployment to vacancy ratio } & & & & & & & -0.038 & -0.040 & -0.041 \\
\hline & & & & & & & $(0.036)$ & $(0.067)$ & $(0.037)$ \\
\hline \multirow[t]{2}{*}{ Constant } & $4.652^{* * *}$ & $4.221 * * *$ & $4.667 * * *$ & $3.989 * * *$ & $3.677 * * *$ & $3.935^{* * *}$ & $3.497 * * *$ & $2.568^{*}$ & $3.690^{* * *}$ \\
\hline & $(0.112)$ & $(0.458)$ & $(0.112)$ & $(0.572)$ & $(1.182)$ & $(0.624)$ & $(0.675)$ & $(1.359)$ & $(0.733)$ \\
\hline No. of employees & 12150 & 2937 & 9213 & 12150 & 2937 & 9213 & 12150 & 2937 & 9213 \\
\hline R-squared & 0.023 & 0.010 & 0.010 & 0.092 & 0.106 & 0.072 & 0.124 & 0.133 & 0.105 \\
\hline
\end{tabular}


Table 2: Workplace union status and job-related anxiety, union and non-union employees, employee response based.

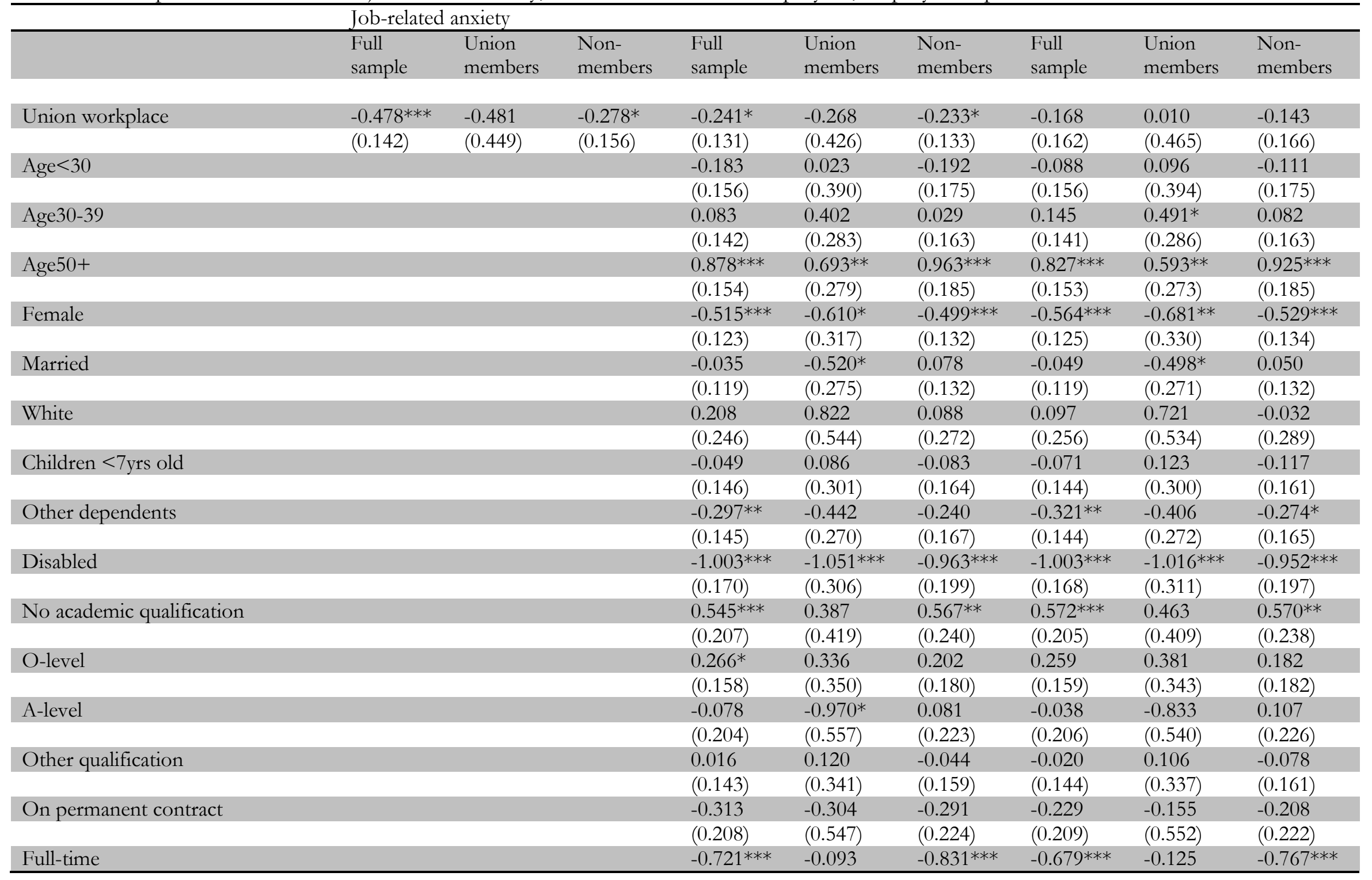




\begin{tabular}{|c|c|c|c|c|c|c|}
\hline & $(0.185)$ & $(0.412)$ & $(0.205)$ & $(0.183)$ & $(0.418)$ & $(0.202)$ \\
\hline \multirow[t]{2}{*}{ Works over 48 hours } & $-1.035^{* * *}$ & $-0.641 * *$ & $-1.138^{* * *}$ & $-1.092^{* * *}$ & $-0.756^{* * *}$ & $-1.185^{* * *}$ \\
\hline & $(0.119)$ & $(0.248)$ & $(0.135)$ & $(0.118)$ & $(0.241)$ & $(0.134)$ \\
\hline \multirow[t]{2}{*}{ Skill same as required } & $0.547 * * *$ & $0.703 * * *$ & $0.518^{* * *}$ & $0.511 * * *$ & $0.647 * * *$ & $0.487 * * *$ \\
\hline & $(0.098)$ & $(0.208)$ & $(0.110)$ & $(0.097)$ & $(0.205)$ & $(0.109)$ \\
\hline \multirow[t]{2}{*}{ Professional } & 0.012 & -0.298 & 0.095 & 0.097 & -0.633 & 0.221 \\
\hline & $(0.223)$ & $(0.534)$ & $(0.240)$ & $(0.231)$ & $(0.609)$ & $(0.239)$ \\
\hline \multirow[t]{2}{*}{ Associate professional \& technical } & $0.402^{*}$ & $1.586^{* * *}$ & 0.136 & $0.384^{*}$ & $1.327 * * *$ & 0.149 \\
\hline & $(0.211)$ & $(0.512)$ & $(0.211)$ & $(0.209)$ & $(0.501)$ & $(0.208)$ \\
\hline \multirow[t]{2}{*}{ Admin. \& secretarial } & $0.365^{*}$ & 0.337 & 0.342 & $0.475^{* *}$ & 0.424 & $0.450 *$ \\
\hline & $(0.222)$ & $(0.482)$ & $(0.239)$ & $(0.220)$ & $(0.464)$ & $(0.236)$ \\
\hline \multirow{2}{*}{ Skilled trades plant \& mach. } & $1.096 * * *$ & $1.274 * * *$ & $1.018^{* * *}$ & $1.105^{* * *}$ & $1.136^{* * *}$ & $1.025^{* * *}$ \\
\hline & $(0.206)$ & $(0.426)$ & $(0.233)$ & $(0.209)$ & $(0.437)$ & $(0.237)$ \\
\hline \multirow[t]{2}{*}{ Personal \& customer services } & $0.538 * *$ & 0.280 & $0.556 * *$ & $0.416^{*}$ & 0.046 & $0.444^{*}$ \\
\hline & $(0.223)$ & $(0.508)$ & $(0.241)$ & $(0.223)$ & $(0.499)$ & $(0.242)$ \\
\hline \multirow[t]{2}{*}{ Elementary occupations } & $0.995^{* * *}$ & $1.579 * * *$ & $0.843^{* * *}$ & $1.058 * * *$ & $1.498^{* * *}$ & $0.936^{* * *}$ \\
\hline & $(0.250)$ & $(0.525)$ & $(0.276)$ & $(0.250)$ & $(0.532)$ & $(0.275)$ \\
\hline \multirow[t]{2}{*}{ Trade union member } & $-0.451 * * *$ & & & $-0.364 * *$ & & \\
\hline & $(0.157)$ & & & $(0.158)$ & & \\
\hline \multirow[t]{2}{*}{ Gross weekly pay $<=110$} & $0.942^{* * *}$ & $1.245^{*}$ & $0.819 * * *$ & $0.868^{* * *}$ & 1.123 & $0.773 * * *$ \\
\hline & $(0.273)$ & $(0.667)$ & $(0.290)$ & $(0.266)$ & $(0.706)$ & $(0.284)$ \\
\hline \multirow[t]{2}{*}{ Gross weekly pay $111-180$} & 0.355 & 0.845 & 0.272 & 0.290 & 0.782 & 0.236 \\
\hline & $(0.235)$ & $(0.572)$ & $(0.251)$ & $(0.231)$ & $(0.563)$ & $(0.250)$ \\
\hline \multirow[t]{2}{*}{ Gross weekly pay $261-360$} & $-0.603 * * *$ & -0.453 & $-0.618^{* * *}$ & $-0.539 * * *$ & -0.410 & $-0.542^{* *}$ \\
\hline & $(0.189)$ & $(0.411)$ & $(0.214)$ & $(0.187)$ & $(0.408)$ & $(0.212)$ \\
\hline \multirow[t]{2}{*}{ Gross weekly pay 361p } & $-0.745^{* * *}$ & -0.508 & $-0.830^{* * *}$ & $-0.589 * * *$ & -0.392 & $-0.653 * * *$ \\
\hline & $(0.189)$ & $(0.439)$ & $(0.208)$ & $(0.188)$ & $(0.417)$ & $(0.212)$ \\
\hline \multirow[t]{2}{*}{ Covered } & & & & -0.245 & -0.565 & -0.196 \\
\hline & & & & $(0.189)$ & $(0.350)$ & $(0.214)$ \\
\hline \multirow[t]{2}{*}{ Union membership encouraged } & & & & 0.062 & -0.022 & 0.226 \\
\hline & & & & $(0.188)$ & $(0.291)$ & $(0.213)$ \\
\hline \multirow[t]{2}{*}{ More than one union present } & & & & 0.756 & $1.225^{* * *}$ & 0.091 \\
\hline & & & & $(0.460)$ & $(0.437)$ & $(0.616)$ \\
\hline \multirow[t]{2}{*}{ Log workplace age } & & & & -0.075 & -0.137 & -0.056 \\
\hline & & & & $(0.062)$ & $(0.117)$ & $(0.070)$ \\
\hline Sole establishment & & & & $0.238^{*}$ & 0.098 & $0.299 * *$ \\
\hline
\end{tabular}




\begin{tabular}{|c|c|c|c|c|c|c|c|c|c|}
\hline & & & & & & & $(0.137)$ & $(0.341)$ & $(0.147)$ \\
\hline \multirow[t]{2}{*}{ No. of employees/1000 } & & & & & & & -0.003 & 0.051 & -0.099 \\
\hline & & & & & & & $(0.092)$ & $(0.154)$ & $(0.102)$ \\
\hline \multirow[t]{2}{*}{ Manufacturing } & & & & & & & 0.198 & 0.633 & 0.046 \\
\hline & & & & & & & $(0.198)$ & $(0.428)$ & $(0.210)$ \\
\hline \multirow[t]{2}{*}{ Construction } & & & & & & & $0.726 * * *$ & 0.679 & $0.675^{* *}$ \\
\hline & & & & & & & $(0.256)$ & $(0.742)$ & $(0.279)$ \\
\hline \multirow{2}{*}{ Wholesale \& retail trade } & & & & & & & $0.593^{* * *}$ & $0.915^{*}$ & $0.511 * *$ \\
\hline & & & & & & & $(0.199)$ & $(0.520)$ & $(0.207)$ \\
\hline \multirow[t]{2}{*}{ Hotel and restaurant } & & & & & & & 0.275 & 0.795 & 0.048 \\
\hline & & & & & & & $(0.268)$ & $(0.512)$ & $(0.286)$ \\
\hline \multirow[t]{2}{*}{ Public \& community services } & & & & & & & $0.913^{* * *}$ & 0.613 & $0.959 * * *$ \\
\hline & & & & & & & $(0.260)$ & $(0.486)$ & $(0.290)$ \\
\hline \multirow[t]{2}{*}{ Education } & & & & & & & $0.741 * *$ & $1.237^{*}$ & $0.820 * *$ \\
\hline & & & & & & & $(0.343)$ & $(0.676)$ & $(0.338)$ \\
\hline \multirow[t]{2}{*}{ Health } & & & & & & & $1.211 * * *$ & $1.126^{* *}$ & $1.044 * * *$ \\
\hline & & & & & & & $(0.248)$ & $(0.558)$ & $(0.256)$ \\
\hline \multirow[t]{2}{*}{ Urban area } & & & & & & & $-0.375^{* *}$ & -0.311 & $-0.390^{* *}$ \\
\hline & & & & & & & $(0.160)$ & $(0.271)$ & $(0.184)$ \\
\hline \multirow[t]{2}{*}{ Unemployment to vacancy ratio } & & & & & & & -0.027 & -0.016 & -0.025 \\
\hline & & & & & & & $(0.028)$ & $(0.054)$ & $(0.031)$ \\
\hline \multirow[t]{2}{*}{ Constant } & $1.656^{* * *}$ & $1.362 * * *$ & $1.666^{* * *}$ & $2.412^{* * *}$ & 0.548 & $2.699 * * *$ & $2.551 * * *$ & 0.796 & $2.823^{* * *}$ \\
\hline & $(0.102)$ & $(0.425)$ & $(0.103)$ & $(0.470)$ & $(1.109)$ & $(0.508)$ & $(0.570)$ & $(1.285)$ & $(0.625)$ \\
\hline No. of employees & 12150 & 2937 & 9213 & 12150 & 2937 & 9213 & 12150 & 2937 & 9213 \\
\hline R-squared & 0.003 & 0.001 & 0.001 & 0.091 & 0.062 & 0.103 & 0.101 & 0.076 & 0.112 \\
\hline
\end{tabular}

Robust standard errors in parenthese

Standard errors adjusted for workplace clusters

$* * * \mathrm{p}<0.01,{ }^{* *} \mathrm{p}<0.05,{ }^{*} \mathrm{p}<0.1$ 
Table 3: Union co-worker(s) and non-union employee wellbeing.

\begin{tabular}{|c|c|c|c|c|c|c|}
\hline & \multicolumn{3}{|c|}{ Job satisfaction } & \multicolumn{3}{|c|}{ Job-related anxiety } \\
\hline \multirow[t]{2}{*}{ Union co-worker(s) } & $-0.717 * * *$ & $-0.664 * * *$ & $-0.496^{* * *}$ & -0.201 & -0.107 & -0.058 \\
\hline & $(0.190)$ & $(0.181)$ & $(0.192)$ & $(0.159)$ & $(0.134)$ & $(0.152)$ \\
\hline \multirow[t]{2}{*}{ Age $<30$} & & -0.138 & 0.001 & & -0.181 & -0.108 \\
\hline & & $(0.188)$ & $(0.185)$ & & $(0.175)$ & $(0.175)$ \\
\hline \multirow[t]{2}{*}{ Age30-39 } & & -0.050 & 0.034 & & 0.034 & 0.083 \\
\hline & & $(0.185)$ & $(0.181)$ & & $(0.163)$ & $(0.163)$ \\
\hline \multirow[t]{2}{*}{ Age50+ } & & $0.591 * * *$ & $0.498^{* * *}$ & & $0.966^{* * *}$ & $0.926^{* * *}$ \\
\hline & & $(0.194)$ & $(0.190)$ & & $(0.185)$ & $(0.185)$ \\
\hline \multirow[t]{2}{*}{ Female } & & 0.237 & 0.126 & & $-0.500 * * *$ & $-0.528^{* * *}$ \\
\hline & & $(0.149)$ & $(0.148)$ & & $(0.132)$ & $(0.134)$ \\
\hline \multirow[t]{2}{*}{ Married } & & $0.418^{* * *}$ & $0.399 * * *$ & & 0.069 & 0.047 \\
\hline & & $(0.144)$ & $(0.143)$ & & $(0.131)$ & $(0.132)$ \\
\hline \multirow[t]{2}{*}{ White } & & -0.121 & -0.263 & & 0.084 & -0.035 \\
\hline & & $(0.395)$ & $(0.415)$ & & $(0.271)$ & $(0.288)$ \\
\hline \multirow[t]{2}{*}{ Children $<7$ yrs old } & & -0.096 & -0.188 & & -0.082 & -0.117 \\
\hline & & (0.199) & $(0.185)$ & & $(0.164)$ & $(0.161)$ \\
\hline \multirow[t]{2}{*}{ Other dependents } & & -0.200 & $-0.304^{*}$ & & -0.244 & $-0.276^{*}$ \\
\hline & & $(0.190)$ & $(0.184)$ & & $(0.168)$ & $(0.166)$ \\
\hline \multirow[t]{2}{*}{ Disabled } & & $-0.455^{* *}$ & $-0.424 * *$ & & $-0.964 * * *$ & $-0.953^{* * *}$ \\
\hline & & $(0.219)$ & $(0.212)$ & & $(0.199)$ & $(0.197)$ \\
\hline \multirow[t]{2}{*}{ No academic qualification } & & $0.622 * *$ & $0.566 * *$ & & $0.578^{* *}$ & $0.571 * *$ \\
\hline & & $(0.290)$ & $(0.273)$ & & $(0.241)$ & $(0.238)$ \\
\hline \multirow[t]{2}{*}{ O-level } & & $0.560 * *$ & $0.479 * *$ & & 0.208 & 0.183 \\
\hline & & $(0.222)$ & $(0.215)$ & & $(0.181)$ & $(0.183)$ \\
\hline \multirow[t]{2}{*}{ A-level } & & 0.280 & 0.310 & & 0.077 & 0.105 \\
\hline & & $(0.240)$ & $(0.233)$ & & $(0.223)$ & $(0.226)$ \\
\hline \multirow[t]{2}{*}{ Other qualification } & & 0.219 & 0.109 & & -0.040 & -0.079 \\
\hline & & $(0.206)$ & $(0.199)$ & & $(0.160)$ & $(0.161)$ \\
\hline \multirow[t]{2}{*}{ On permanent contract } & & $1.148^{* * *}$ & $1.335^{* * *}$ & & -0.288 & -0.209 \\
\hline & & $(0.255)$ & $(0.249)$ & & $(0.226)$ & $(0.223)$ \\
\hline \multirow[t]{2}{*}{ Full-time } & & -0.299 & -0.177 & & $-0.833 * * *$ & $-0.768^{* * *}$ \\
\hline & & $(0.218)$ & $(0.208)$ & & $(0.205)$ & $(0.202)$ \\
\hline Works over 48 hours & & 0.207 & 0.097 & & $-1.137 * * *$ & $-1.186^{* * *}$ \\
\hline
\end{tabular}




\begin{tabular}{|c|c|c|c|c|}
\hline & $(0.159)$ & $(0.154)$ & $(0.135)$ & $(0.134)$ \\
\hline \multirow[t]{2}{*}{ Skill same as required } & $1.443^{* * *}$ & $1.371 * * *$ & $0.527 * * *$ & $0.490^{* * *}$ \\
\hline & $(0.124)$ & $(0.122)$ & $(0.110)$ & $(0.109)$ \\
\hline \multirow[t]{2}{*}{ Professional } & $-2.018^{* * *}$ & $-1.736 * * *$ & 0.089 & 0.222 \\
\hline & $(0.301)$ & $(0.310)$ & $(0.239)$ & $(0.239)$ \\
\hline \multirow{2}{*}{ Associate professional \& technical } & $-1.599 * * *$ & $-1.540 * * *$ & 0.133 & 0.148 \\
\hline & $(0.238)$ & $(0.229)$ & $(0.211)$ & $(0.209)$ \\
\hline \multirow{2}{*}{ Admin. \& secretarial } & $-1.845^{* * *}$ & $-1.653 * * *$ & 0.340 & $0.449 *$ \\
\hline & $(0.249)$ & $(0.239)$ & $(0.239)$ & $(0.237)$ \\
\hline \multirow{2}{*}{ Skilled trades plant \& mach. } & $-2.046^{* * *}$ & $-1.988^{* * *}$ & $1.001 * * *$ & $1.020^{* * *}$ \\
\hline & $(0.261)$ & $(0.250)$ & $(0.234)$ & $(0.237)$ \\
\hline \multirow[t]{2}{*}{ Personal \& customer services } & $-1.355^{* * *}$ & $-1.510^{* * *}$ & $0.535^{* *}$ & $0.437^{*}$ \\
\hline & $(0.253)$ & $(0.245)$ & $(0.241)$ & $(0.242)$ \\
\hline \multirow[t]{2}{*}{ Elementary occupations } & $-1.682^{* * *}$ & $-1.588 * * *$ & $0.826^{* * *}$ & $0.929 * * *$ \\
\hline & $(0.322)$ & $(0.316)$ & $(0.275)$ & $(0.275)$ \\
\hline \multirow[t]{2}{*}{ Trade union member } & 0.000 & 0.000 & 0.000 & 0.000 \\
\hline & $(0.000)$ & $(0.000)$ & $(0.000)$ & $(0.000)$ \\
\hline \multirow[t]{2}{*}{ Gross weekly pay $<=110$} & $0.636^{* *}$ & $0.554^{*}$ & $0.824 * * *$ & $0.771 * * *$ \\
\hline & $(0.308)$ & $(0.297)$ & $(0.290)$ & $(0.285)$ \\
\hline \multirow[t]{2}{*}{ Gross weekly pay $111-180$} & 0.159 & 0.040 & 0.272 & 0.235 \\
\hline & $(0.276)$ & $(0.274)$ & $(0.252)$ & $(0.250)$ \\
\hline \multirow[t]{2}{*}{ Gross weekly pay $261-360$} & -0.256 & -0.126 & $-0.617^{* * *} *$ & $-0.541 * *$ \\
\hline & $(0.216)$ & $(0.214)$ & $(0.213)$ & $(0.212)$ \\
\hline \multirow[t]{2}{*}{ Gross weekly pay 361p } & -0.098 & 0.279 & $-0.835^{* * *}$ & $-0.654 * * *$ \\
\hline & $(0.242)$ & $(0.236)$ & $(0.208)$ & $(0.212)$ \\
\hline \multirow[t]{2}{*}{ Covered } & & $-0.409^{*}$ & & -0.231 \\
\hline & & $(0.243)$ & & $(0.210)$ \\
\hline \multirow[t]{2}{*}{ Union membership encouraged } & & 0.303 & & 0.185 \\
\hline & & $(0.270)$ & & $(0.210)$ \\
\hline \multirow[t]{2}{*}{ More than one union present } & & 0.495 & & 0.059 \\
\hline & & $(0.688)$ & & $(0.618)$ \\
\hline \multirow[t]{2}{*}{ Log workplace age } & & $-0.145^{*}$ & & -0.056 \\
\hline & & $(0.084)$ & & $(0.070)$ \\
\hline \multirow[t]{2}{*}{ Sole establishment } & & $0.880 * * *$ & & $0.314 * *$ \\
\hline & & $(0.184)$ & & $(0.149)$ \\
\hline No. of employees /1000 & & $-0.446^{* * *}$ & & -0.112 \\
\hline
\end{tabular}




\begin{tabular}{|c|c|c|c|c|c|c|}
\hline & & & $(0.138)$ & & & $(0.104)$ \\
\hline \multirow[t]{2}{*}{ Manufacturing } & & & -0.031 & & & 0.029 \\
\hline & & & $(0.292)$ & & & $(0.207)$ \\
\hline \multirow[t]{2}{*}{ Construction } & & & $1.418^{* * *}$ & & & $0.680^{* *}$ \\
\hline & & & $(0.375)$ & & & $(0.281)$ \\
\hline \multirow{2}{*}{ Wholesale \& retail trade } & & & $0.909 * * *$ & & & $0.513^{* *}$ \\
\hline & & & $(0.252)$ & & & $(0.207)$ \\
\hline \multirow{2}{*}{ Hotel and restaurant } & & & $0.637^{*}$ & & & 0.037 \\
\hline & & & $(0.358)$ & & & $(0.285)$ \\
\hline \multirow{2}{*}{ Public \& community services } & & & $1.097 * * *$ & & & $0.951 * * *$ \\
\hline & & & $(0.418)$ & & & $(0.289)$ \\
\hline \multirow[t]{2}{*}{ Education } & & & $2.184 * * *$ & & & $0.802^{* *}$ \\
\hline & & & $(0.544)$ & & & $(0.336)$ \\
\hline \multirow[t]{2}{*}{ Health } & & & $2.229 * * *$ & & & $1.023^{* * *}$ \\
\hline & & & $(0.295)$ & & & $(0.249)$ \\
\hline \multirow[t]{2}{*}{ Urban area } & & & -0.225 & & & $-0.385^{* *}$ \\
\hline & & & $(0.224)$ & & & $(0.184)$ \\
\hline \multirow[t]{2}{*}{ Unemployment to vacancy ratio } & & & -0.036 & & & -0.023 \\
\hline & & & $(0.038)$ & & & $(0.031)$ \\
\hline \multirow[t]{2}{*}{ Constant } & $4.636 * * *$ & $3.953 * * *$ & $3.735^{* * *}$ & $1.663^{* * *}$ & $2.675^{* * *}$ & $2.818^{* * *}$ \\
\hline & $(0.120)$ & $(0.635)$ & $(0.738)$ & $(0.107)$ & $(0.514)$ & $(0.629)$ \\
\hline No. of employees & 9213 & 9213 & 9213 & 9213 & 9213 & 9213 \\
\hline R-squared & 0.005 & 0.068 & 0.104 & 0.000 & 0.103 & 0.112 \\
\hline
\end{tabular}

Robust standard errors in parentheses

Standard errors adjusted for workplace clusters

*** $\mathrm{p}<0.01,{ }^{* *} \mathrm{p}<0.05, * \mathrm{p}<0.1$ 
Table 4: Union status and employee wellbeing, non-union employees sub-sample.

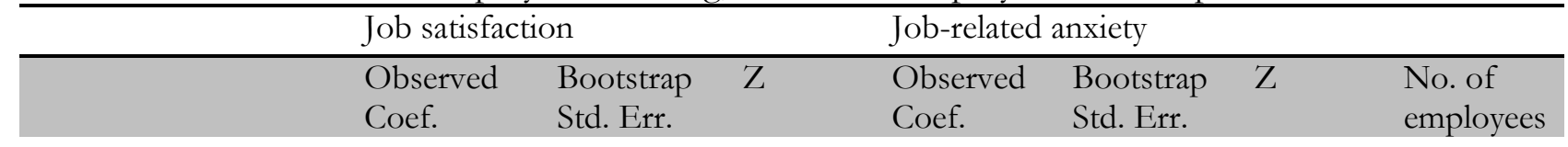

Union workplace

$\begin{array}{lccccccc}\text { ATT } & -0.709 & 0.159 & -4.46 & -0.008 & 0.134 & -0.06 & 9213 \\ \text { Union co-worker(s) } & & & & & & & \\ \text { ATT } & -0.437 & 0.157 & -2.78 & 0.004 & 0.136 & 0.29 & 9213\end{array}$

Bootstrap standard errors from 250 replications based on 1034 clusters/workplaces. 
Table 5: Estimated coefficients from probit models generating the propensity scores

\begin{tabular}{|c|c|c|}
\hline & Union workplace & Union co-worker \\
\hline \multirow[t]{2}{*}{ Age $<30$} & $-0.243^{* * *}$ & $-0.218^{* * *}$ \\
\hline & $(0.042)$ & $(0.040)$ \\
\hline \multirow[t]{2}{*}{ Age30-39 } & $-0.109 * * *$ & $-0.120^{* * *}$ \\
\hline & $(0.041)$ & $(0.040)$ \\
\hline \multirow[t]{2}{*}{ Age50+ } & -0.019 & 0.014 \\
\hline & $(0.043)$ & $(0.042)$ \\
\hline \multirow[t]{2}{*}{ Female } & $0.068^{* *}$ & 0.021 \\
\hline & $(0.034)$ & $(0.033)$ \\
\hline \multirow[t]{2}{*}{ Married } & $0.094 * * *$ & 0.033 \\
\hline & $(0.032)$ & $(0.031)$ \\
\hline \multirow[t]{2}{*}{ White } & $-0.110^{*}$ & $-0.125^{* *}$ \\
\hline & $(0.061)$ & $(0.060)$ \\
\hline \multirow[t]{2}{*}{ Children $<7$ yrs old } & 0.024 & 0.006 \\
\hline & $(0.040)$ & $(0.038)$ \\
\hline \multirow[t]{2}{*}{ Other dependents } & 0.057 & 0.013 \\
\hline & $(0.042)$ & $(0.041)$ \\
\hline \multirow[t]{2}{*}{ Disabled } & -0.012 & -0.029 \\
\hline & $(0.046)$ & $(0.045)$ \\
\hline \multirow[t]{2}{*}{ No academic qualification } & $-0.242^{* * *}$ & $-0.186^{* * *}$ \\
\hline & $(0.056)$ & $(0.055)$ \\
\hline \multirow[t]{2}{*}{ O-level } & $-0.169^{* * *}$ & $-0.107 * *$ \\
\hline & $(0.046)$ & $(0.044)$ \\
\hline \multirow[t]{2}{*}{ A-level } & -0.043 & -0.088 \\
\hline & $(0.055)$ & $(0.054)$ \\
\hline \multirow[t]{2}{*}{ Other qualification } & $-0.128^{* * *}$ & $-0.082^{* *}$ \\
\hline & $(0.041)$ & $(0.040)$ \\
\hline \multirow[t]{2}{*}{ On permanent contract } & $-0.178^{* * *}$ & -0.083 \\
\hline & $(0.054)$ & $(0.052)$ \\
\hline \multirow[t]{2}{*}{ Full-time } & -0.062 & $-0.105^{* *}$ \\
\hline & $(0.050)$ & $(0.049)$ \\
\hline \multirow[t]{2}{*}{ Works over 48 hours } & -0.024 & -0.029 \\
\hline & $(0.032)$ & $(0.031)$ \\
\hline \multirow{2}{*}{ Skill same as required } & $-0.117 * * *$ & $-0.071 * * *$ \\
\hline & $(0.028)$ & $(0.027)$ \\
\hline
\end{tabular}




\begin{tabular}{|c|c|c|}
\hline \multirow[t]{2}{*}{ Professional } & 0.066 & 0.023 \\
\hline & $(0.060)$ & $(0.058)$ \\
\hline \multirow[t]{2}{*}{ Associate professional \& technical } & 0.052 & $0.108^{* *}$ \\
\hline & $(0.052)$ & $(0.050)$ \\
\hline \multirow[t]{2}{*}{ Admin. \& secretarial } & 0.005 & -0.021 \\
\hline & $(0.053)$ & $(0.051)$ \\
\hline \multirow[t]{2}{*}{ Skilled trades plant \& mach. } & $0.269 * * *$ & $0.097 *$ \\
\hline & $(0.055)$ & $(0.053)$ \\
\hline \multirow[t]{2}{*}{ Personal \& customer services } & $0.273^{* * *}$ & 0.009 \\
\hline & $(0.057)$ & $(0.055)$ \\
\hline \multirow[t]{2}{*}{ Elementary occupations } & $0.242^{* * *}$ & 0.053 \\
\hline & $(0.062)$ & $(0.060)$ \\
\hline \multirow[t]{2}{*}{ Gross weekly pay $<=110$} & $-0.193^{* * *}$ & $-0.206^{* * *}$ \\
\hline & $(0.067)$ & $(0.064)$ \\
\hline \multirow[t]{2}{*}{ Gross weekly pay $111-180$} & 0.013 & 0.016 \\
\hline & $(0.056)$ & $(0.055)$ \\
\hline \multirow[t]{2}{*}{ Gross weekly pay 261-360 } & 0.035 & -0.003 \\
\hline & $(0.045)$ & $(0.043)$ \\
\hline \multirow{2}{*}{ Gross weekly pay 361p } & $0.119^{* *}$ & 0.002 \\
\hline & $(0.047)$ & $(0.045)$ \\
\hline \multirow[t]{2}{*}{ Log workplace age } & $0.102^{* * *}$ & $0.054 * * *$ \\
\hline & $(0.013)$ & $(0.013)$ \\
\hline \multirow[t]{2}{*}{ Sole establishment } & $-0.543^{* * *}$ & $-0.351 * * *$ \\
\hline & $(0.032)$ & $(0.030)$ \\
\hline \multirow[t]{2}{*}{ Urban area } & $-0.267 * * *$ & $-0.123^{* * *}$ \\
\hline & $(0.037)$ & $(0.036)$ \\
\hline \multirow[t]{2}{*}{ Unemployment to vacancy ratio } & -0.011 & $0.024 * * *$ \\
\hline & $(0.009)$ & $(0.009)$ \\
\hline \multirow[t]{2}{*}{ North east } & $0.304 * * *$ & -0.086 \\
\hline & $(0.101)$ & $(0.099)$ \\
\hline \multirow[t]{2}{*}{ North west } & -0.110 & -0.128 \\
\hline & $(0.084)$ & $(0.082)$ \\
\hline \multirow[t]{2}{*}{ Yorkshire \& the Humber } & $0.372^{* * *}$ & 0.131 \\
\hline & $(0.091)$ & $(0.089)$ \\
\hline \multirow[t]{2}{*}{ East midlands } & 0.080 & -0.048 \\
\hline & $(0.092)$ & $(0.090)$ \\
\hline \multirow[t]{2}{*}{ West midlands } & $-0.163^{*}$ & $-0.325^{* * *}$ \\
\hline & $(0.089)$ & $(0.086)$ \\
\hline
\end{tabular}




\begin{tabular}{lll}
\hline East of England & -0.069 & $-0.268^{* * *}$ \\
\hline London & $(0.089)$ & $(0.087)$ \\
& $-0.348^{* * *}$ & $-0.656^{* * *}$ \\
\hline South East & $(0.108)$ & $(0.104)$ \\
& $-0.312^{* * *}$ & -0.109 \\
South West & $(0.085)$ & $(0.082)$ \\
& 0.004 & -0.092 \\
\hline Scotland & $(0.088)$ & $(0.086)$ \\
& $-0.159^{*}$ & -0.098 \\
Constant & $(0.092)$ & $(0.089)$ \\
& 0.219 & $0.593^{* * *}$ \\
& $(0.144)$ & $(0.140)$ \\
\hline Log likelihood & & -6171.595 \\
\hline LR Chi2(41) & -5712.456 & 428.62 \\
No. of employees & 845.84 & 9,213 \\
\hline Standard errors in parentheses & 9,213 &
\end{tabular}

Standard errors in parentheses

*** $\mathrm{p}<0.01,{ }^{* *} \mathrm{p}<0.05,{ }^{*} \mathrm{p}<0.1$ 
Table 6: Results from overall covariate imbalance test.

\begin{tabular}{llllll}
\hline Sample & Pseudo R2 & LR chi2 & p>chi2 & MeanBias & MedBias \\
\hline Union workplace & & & & & \\
Raw & & & & & \\
Matched & 0.069 & 845.84 & 0.000 & 6.9 & 3.9 \\
& 0.003 & 31.08 & 0.870 & 1.7 & 1.3 \\
Union co-worker & & & & & \\
Raw & 0.034 & 428.62 & 0.000 & 4.7 & 3.2 \\
Matched & 0.004 & 45.12 & 0.304 & 1.6 & 1.1 \\
\hline
\end{tabular}


Table 7: Outcome measures, including constituent domains, by membership status

\begin{tabular}{|c|c|c|c|c|c|c|c|c|c|c|c|c|}
\hline \multirow[b]{2}{*}{ Variable } & \multicolumn{4}{|l|}{ All } & \multicolumn{4}{|c|}{ Non-members } & \multicolumn{4}{|c|}{ Members } \\
\hline & Mean & Std. Dev. & Min & $\operatorname{Max}$ & Mean & Std. Dev. & Min & Max & Mean & Std. Dev. & Min & Max \\
\hline \multicolumn{13}{|l|}{ Job Satisfaction } \\
\hline Achievement & 3.749 & 0.933 & 1 & 5 & 3.798 & 0.909 & 1 & 5 & 3.597 & 0.986 & 1 & 5 \\
\hline Initiative & 3.814 & 0.933 & 1 & 5 & 3.859 & 0.905 & 1 & 5 & 3.675 & 1.003 & 1 & 5 \\
\hline Influence & 3.571 & 0.948 & 1 & 5 & 3.626 & 0.918 & 1 & 5 & 3.398 & 1.018 & 1 & 5 \\
\hline Training & 3.301 & 1.083 & 1 & 5 & 3.338 & 1.068 & 1 & 5 & 3.187 & 1.124 & 1 & 5 \\
\hline Job security & 3.544 & 1.007 & 1 & 5 & 3.613 & 0.964 & 1 & 5 & 3.327 & 1.103 & 1 & 5 \\
\hline Work itself & 3.766 & 0.903 & 1 & 5 & 3.811 & 0.881 & 1 & 5 & 3.628 & 0.956 & 1 & 5 \\
\hline Decision making & 3.214 & 1.013 & 1 & 5 & 3.291 & 0.986 & 1 & 5 & 2.970 & 1.057 & 1 & 5 \\
\hline Job satisfaction, additive measure & 3.736 & 5.086 & -14 & 14 & 4.136 & 4.880 & -14 & 14 & 2.480 & 5.501 & -14 & 14 \\
\hline \multicolumn{13}{|l|}{ Affective $W B$} \\
\hline Tense & 3.302 & 0.983 & 1 & 5 & 3.316 & 0.984 & 1 & 5 & 3.259 & 0.979 & 1 & 5 \\
\hline Calm & 2.891 & 1.055 & 1 & 5 & 2.915 & 1.057 & 1 & 5 & 2.817 & 1.048 & 1 & 5 \\
\hline Relaxed & 2.645 & 1.099 & 1 & 5 & 2.676 & 1.098 & 1 & 5 & 2.546 & 1.097 & 1 & 5 \\
\hline Worried & 3.624 & 0.990 & 1 & 5 & 3.624 & 0.989 & 1 & 5 & 3.626 & 0.993 & 1 & 5 \\
\hline Uneasy & 3.830 & 1.004 & 1 & 5 & 3.855 & 1.002 & 1 & 5 & 3.753 & 1.005 & 1 & 5 \\
\hline Content & 3.008 & 1.080 & 1 & 5 & 3.058 & 1.071 & 1 & 5 & 2.853 & 1.091 & 1 & 5 \\
\hline $\begin{array}{l}\text { Job-related anxiety, additive } \\
\text { measure }\end{array}$ & 1.301 & 4.706 & -12 & 12 & 1.443 & 4.681 & -12 & 12 & 0.853 & 4.756 & -12 & 12 \\
\hline No. of employees & 12150 & & & & 9213 & & & & 2937 & & & \\
\hline No. of workplaces & 1058 & & & & & & & & & & & \\
\hline
\end{tabular}


Table 8: Descriptive statistics, by membership status

\begin{tabular}{|c|c|c|c|c|c|c|c|c|c|c|c|c|}
\hline \multirow[b]{2}{*}{ Variable } & \multicolumn{4}{|l|}{ All } & \multicolumn{4}{|c|}{ Non-members } & \multicolumn{4}{|c|}{ Members } \\
\hline & Mean & $\begin{array}{l}\text { Std. } \\
\text { Dev. }\end{array}$ & Min & $\operatorname{Max}$ & Mean & $\begin{array}{l}\text { Std. } \\
\text { Dev. }\end{array}$ & Min & $\operatorname{Max}$ & Mean & $\begin{array}{l}\text { Std. } \\
\text { Dev. }\end{array}$ & Min & $\overline{\operatorname{Max}}$ \\
\hline Union workplace & 0.514 & 0.500 & 0 & 1 & 0.384 & 0.486 & 0 & 1 & 0.922 & 0.268 & 0 & 1 \\
\hline Union co-worker & 0.620 & 0.486 & 0 & 1 & 0.498 & 0.500 & 0 & 1 & 1.000 & 0.000 & 1 & 1 \\
\hline Age $<30$ & 0.251 & 0.434 & 0 & 1 & 0.294 & 0.455 & 0 & 1 & 0.119 & 0.324 & 0 & 1 \\
\hline Age30-39 & 0.261 & 0.439 & 0 & 1 & 0.264 & 0.441 & 0 & 1 & 0.253 & 0.435 & 0 & 1 \\
\hline Age 50+ & 0.239 & 0.426 & 0 & 1 & 0.216 & 0.412 & 0 & 1 & 0.309 & 0.462 & 0 & 1 \\
\hline Female & 0.464 & 0.499 & 0 & 1 & 0.498 & 0.500 & 0 & 1 & 0.360 & 0.480 & 0 & 1 \\
\hline Married & 0.665 & 0.472 & 0 & 1 & 0.643 & 0.479 & 0 & 1 & 0.736 & 0.441 & 0 & 1 \\
\hline White & 0.948 & 0.222 & 0 & 1 & 0.944 & 0.230 & 0 & 1 & 0.960 & 0.196 & 0 & 1 \\
\hline Children $<7$ yrs old & 0.184 & 0.388 & 0 & 1 & 0.186 & 0.389 & 0 & 1 & 0.178 & 0.383 & 0 & 1 \\
\hline Other dependents & 0.138 & 0.345 & 0 & 1 & 0.124 & 0.330 & 0 & 1 & 0.179 & 0.384 & 0 & 1 \\
\hline Disabled & 0.112 & 0.316 & 0 & 1 & 0.100 & 0.301 & 0 & 1 & 0.150 & 0.357 & 0 & 1 \\
\hline No academic qualification & 0.164 & 0.370 & 0 & 1 & 0.151 & 0.358 & 0 & 1 & 0.205 & 0.404 & 0 & 1 \\
\hline O-level & 0.247 & 0.432 & 0 & 1 & 0.243 & 0.429 & 0 & 1 & 0.261 & 0.439 & 0 & 1 \\
\hline A-level & 0.094 & 0.292 & 0 & 1 & 0.099 & 0.299 & 0 & 1 & 0.077 & 0.267 & 0 & 1 \\
\hline Other qualification & 0.320 & 0.467 & 0 & 1 & 0.322 & 0.467 & 0 & 1 & 0.314 & 0.464 & 0 & 1 \\
\hline On permanent contract & 0.932 & 0.251 & 0 & 1 & 0.923 & 0.267 & 0 & 1 & 0.962 & 0.192 & 0 & 1 \\
\hline Full-time & 0.811 & 0.391 & 0 & 1 & 0.793 & 0.406 & 0 & 1 & 0.870 & 0.336 & 0 & 1 \\
\hline Works over 48 hours & 0.506 & 0.500 & 0 & 1 & 0.487 & 0.500 & 0 & 1 & 0.565 & 0.496 & 0 & 1 \\
\hline Skill same as required & 0.413 & 0.492 & 0 & 1 & 0.418 & 0.493 & 0 & 1 & 0.394 & 0.489 & 0 & 1 \\
\hline Professional & 0.086 & 0.280 & 0 & 1 & 0.085 & 0.280 & 0 & 1 & 0.087 & 0.282 & 0 & 1 \\
\hline Associate professional \& Technical & 0.144 & 0.351 & 0 & 1 & 0.146 & 0.353 & 0 & 1 & 0.137 & 0.343 & 0 & 1 \\
\hline Admin. \& secretarial & 0.176 & 0.381 & 0 & 1 & 0.193 & 0.394 & 0 & 1 & 0.123 & 0.328 & 0 & 1 \\
\hline Skilled trades plant \& mach. & 0.193 & 0.395 & 0 & 1 & 0.146 & 0.353 & 0 & 1 & 0.341 & 0.474 & 0 & 1 \\
\hline Personal \& customer services & 0.152 & 0.359 & 0 & 1 & 0.164 & 0.371 & 0 & 1 & 0.112 & 0.315 & 0 & 1 \\
\hline Elementary occupations & 0.111 & 0.314 & 0 & 1 & 0.113 & 0.316 & 0 & 1 & 0.105 & 0.306 & 0 & 1 \\
\hline Union member & 0.242 & 0.428 & 0 & 1 & 0.000 & 0.000 & 0 & 0 & 1.000 & 0.000 & 1 & 1 \\
\hline
\end{tabular}




\begin{tabular}{|c|c|c|c|c|c|c|c|c|c|c|c|c|}
\hline Gross weekly pay $<=110$ & 0.096 & 0.295 & 0 & 1 & 0.115 & 0.319 & 0 & 1 & 0.037 & 0.189 & 0 & 1 \\
\hline Gross weekly pay $111-180$ & 0.092 & 0.289 & 0 & 1 & 0.103 & 0.304 & 0 & 1 & 0.057 & 0.232 & 0 & 1 \\
\hline Gross weekly pay 261-360 & 0.208 & 0.406 & 0 & 1 & 0.201 & 0.400 & 0 & 1 & 0.230 & 0.421 & 0 & 1 \\
\hline Gross weekly pay $361 p$ & 0.421 & 0.494 & 0 & 1 & 0.389 & 0.488 & 0 & 1 & 0.523 & 0.500 & 0 & 1 \\
\hline $\begin{array}{l}\text { Covered, }>50 \% \text { employees' pay set through } \\
\text { negotiation with unions }\end{array}$ & 0.351 & 0.477 & 0 & 1 & 0.218 & 0.413 & 0 & 1 & 0.769 & 0.422 & 0 & 1 \\
\hline Union membership encouraged & 0.141 & 0.348 & 0 & 1 & 0.089 & 0.284 & 0 & 1 & 0.304 & 0.460 & 0 & 1 \\
\hline More than one union present & 0.028 & 0.165 & 0 & 1 & 0.015 & 0.123 & 0 & 1 & 0.067 & 0.250 & 0 & 1 \\
\hline Log workplace age & 3.157 & 1.102 & 0 & 6.802 & 3.072 & 1.072 & 0 & 6.802 & 3.422 & 1.153 & 0 & 6.802 \\
\hline Sole establishment & 0.276 & 0.447 & 0 & 1 & 0.301 & 0.459 & 0 & 1 & 0.198 & 0.398 & 0 & 1 \\
\hline No. of employees/1000 & 0.337 & 0.695 & 0.005 & 7.74 & 0.261 & 0.574 & 0.005 & 7.74 & 0.577 & 0.942 & 0.005 & 7.74 \\
\hline Manufacturing & 0.223 & 0.417 & 0 & 1 & 0.193 & 0.395 & 0 & 1 & 0.318 & 0.466 & 0 & 1 \\
\hline Construction & 0.062 & 0.241 & 0 & 1 & 0.069 & 0.254 & 0 & 1 & 0.040 & 0.195 & 0 & 1 \\
\hline Wholesale \& retail trade & 0.138 & 0.345 & 0 & 1 & 0.160 & 0.366 & 0 & 1 & 0.068 & 0.253 & 0 & 1 \\
\hline Hotel and restaurant & 0.109 & 0.311 & 0 & 1 & 0.095 & 0.293 & 0 & 1 & 0.153 & 0.360 & 0 & 1 \\
\hline Public \& community services & 0.094 & 0.291 & 0 & 1 & 0.083 & 0.276 & 0 & 1 & 0.127 & 0.333 & 0 & 1 \\
\hline Education & 0.040 & 0.196 & 0 & 1 & 0.032 & 0.176 & 0 & 1 & 0.066 & 0.248 & 0 & 1 \\
\hline Health & 0.093 & 0.290 & 0 & 1 & 0.101 & 0.302 & 0 & 1 & 0.065 & 0.247 & 0 & 1 \\
\hline Urban area & 0.802 & 0.398 & 0 & 1 & 0.819 & 0.385 & 0 & 1 & 0.748 & 0.434 & 0 & 1 \\
\hline Unemployment to vacancy ratio & 3.353 & 2.384 & 0 & 9 & 3.385 & 2.423 & 0 & 9 & 3.252 & 2.257 & 0 & 9 \\
\hline No. of employees & 12150 & & & & 9213 & & & & 2937 & & & \\
\hline No. of workplaces & 1058 & & & & & & & & & & & \\
\hline
\end{tabular}


Figure 1: Job satisfaction and job-related anxiety, by union membership status

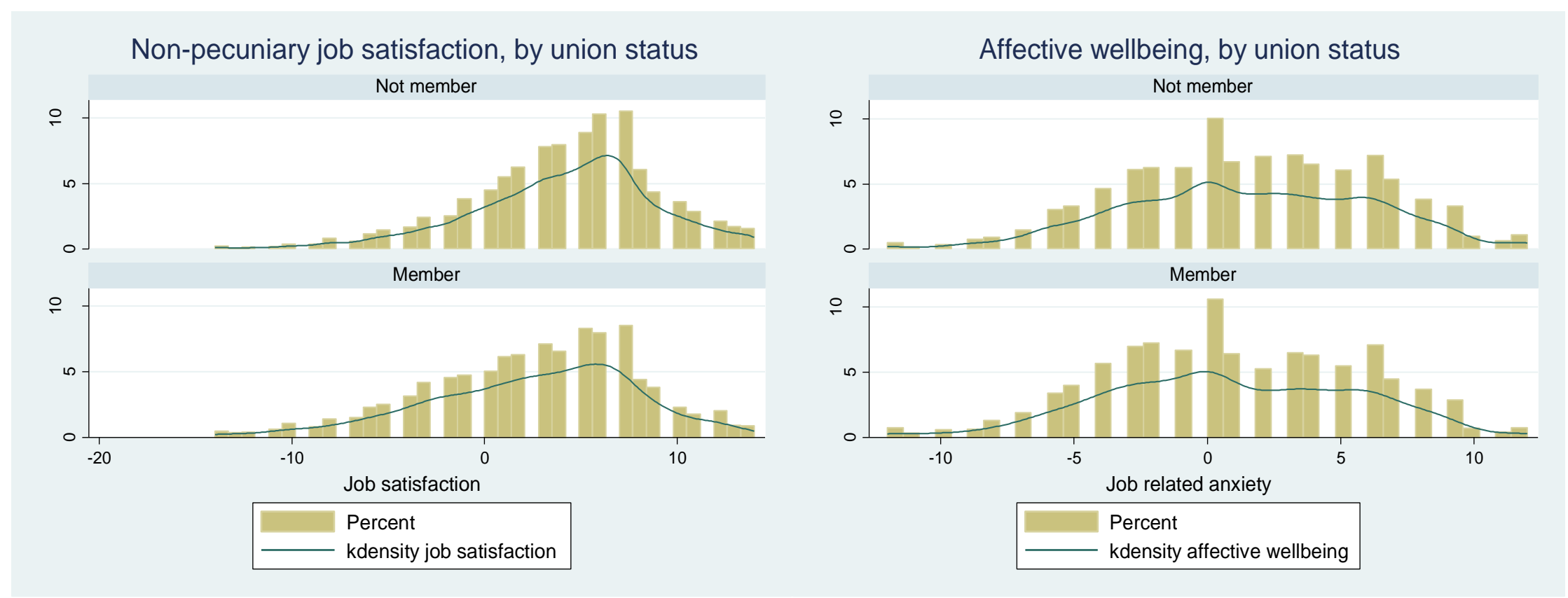

